\title{
Communications Rights, Disability, and Law: The Convention on the Rights of Persons with Disabilities in National Perspective
}

\author{
Gerard Goggin*
}

\begin{abstract}
Communications and media are now recognised as a vital area of disability, especially when it comes to digital technology. In this article, I discuss the way that rights to communication, articulated in the Convention on the Rights of Persons with Disabilities (CRPD), played out in the 2006-2016 period. I trace the evolution of communications as a part of human rights internationally, and then how these rights are considerably advanced with a new formulation in the CRPD. I also analyse the interplay between these communications rights in the CRPD with the law, policy, and regulation at the national level, using the case of Australia. In particular, I discuss a key element of communications rights - universal service (or the entitlement of everyone to telecommunications, and in the present conjuncture, mobile phones and broadband internet). I find that while the CRPD is a useful tool, it has fallen well short in terms of force in the Australian context. In particular, a key obstacle is a striking lack of a comprehensive, overarching legal and policy framework on communications rights. In this situation, I suggest it is imperative to build a comprehensive national legal framework, underpinned by contemporary understandings of disability, and the CRPD, to achieve communications rights for people with disabilities and everyone.
\end{abstract}

\section{INTRODUCTION}

Globally, communication and media have taken on a heightened role in social life, especially with the rise of internet, social, and mobile media technologies. ${ }^{1}$ Use of digital technologies varies widely across societies, groups, and individuals. ${ }^{2}$ New technologies, even commonly used ones such as mobile phones and internet, exhibit uneven and unequal patterns

* This article is an output of my Australian Research Council Future Fellowship project on 'Disability and Digital Technology' (FT130100097).

1 Nancy Baym, Personal Connections in the Digital Age (Polity, 2010); Rich Ling, Taken for Grantedness: The Embedding of Mobile Communication into Society (MIT Press, 2012); José van Dick, The Culture of Connectivity: A Critical History of Social Media (Oxford University Press, 2013); Engin F Isin and Evelyn S Ruppert, Being Digital Citizens (Rowman \& Littlefield, 2015).

2 Gerard Goggin and Mark McLelland (eds), Internationalizing Internet Studies: Beyond Anglophone Paradigms (Routledge, 2009) and Routledge Companion to Global Internet Histories (Routledge, 2017). 
of take-up and use. In addition, media infrastructure, literacies, resources, social and cultural capital are strikingly diverse. ${ }^{3}$ Nonetheless, communications and media are a vital part of contemporary life, especially in relation to people with disabilities and the ongoing project of transformation of disability in society. As disability has emerged as a central concern for societies, especially in relation to law and justice, communication and media have achieved central prominence. ${ }^{5}$ In contemporary social and legal settings, digital technologies often play an essential role in the prospects and capabilities of people with disabilities to participate on an equal basis with their counterparts.

Across various disciplines in social sciences and humanities, research is providing new understandings of the appropriation and role of digital technologies in the lives of people with disabilities. ${ }^{6}$ For instance, there is a growing literature on the new kinds of barriers, exclusions, and challenges that are associated with the introduction and development of digital technology. ${ }^{7}$ The classic example here is the introduction of the Windows 95 Operating System by Microsoft. ${ }^{8}$ For some years, computer users who were blind or had vision impairments could use screen readers deploying synthesised speech to navigate interfaces, and use software and computers. When first introduced, Windows was not compatible with such screen readers. Far from enjoying the boon of such new technology, blind people lost the accessibility of computing they had previously enjoyed. It took considerable advocacy and legal struggle, especially undertaken by the disability movement in the United States (US) invoking the Americans with Disabilities Act of 1990 (ADA), ${ }^{9}$ before Windows rectified the problem, acknowledged the needs of Blind computer users, and redesigned the software. More recently, there is the case of the iPhone. The iPhone was not

3 Jonathon Donner, After Access: Inclusion, Development, and a More Mobile Internet (MIT Press, 2015).

4 Filippo Trevisan, Disability Rights Advocacy and New Media in Britain and America (Routledge, 2016).

$5 \quad$ Beth Haller, Representing Disability in an Ableist World: Essays on Mass Media (Advocado Press, 2010); Katie Ellis and Gerard Goggin, Disability and the Media (Palgrave Macmillan, 2015).

6 Meryl Alper, Digital Youth with Disabilities (MIT Press, 2014) and Giving Voice: Mobile Communication, Disability, and Inequality (MIT Press, 2017); Katie Ellis, Disability and Popular Culture: Focusing Passion, Creating Community, and Expressing Defiance (Ashgate, 2015); Mara Mills, On the Phone: Deafness and Communication Engineering (Duke University Press, 2016); Alan Roulstone, Disability and Technology: International and Interdisciplinary Perspectives (Palgrave, 2016).

$7 \quad$ Paul T Jaeger, Disability and the Internet (Lynne Rienner, 2010); Katie Ellis and Mike Kent, Disability and New Media (Routledge, 2011); Jonathan Lazar, Daniel Goldstein and Anne Taylor, Ensuring Digital Accessibility through Process and Policy (Morgan Kaufmann, 2015); Elizabeth Ellcessor, Restricted Access: Media, Disability, and the Politics of Participation (New York University Press, 2016).

8 On the inaccessibility of early versions of Windows, see, for example, Gerard Goggin and Christopher Newell, Digital Disability: The Social Construction of Disability in New Media (Rowman \& Littlefield, 2003) 120-121. 42 USC $§ 12101$ (ADA). 
launched with a version of the operating system, with 'native' or built-in accessibility features, for which Apple desktop and laptop computers had become renowned. ${ }^{10}$ Again, it took political struggle and recourse to legal action before Apple updated its iOS (iPhone, iPad, and iPod operating systems) to incorporate accessibility features. Subsequently, Apple has won awards from the disability community, and been widely feeted for the 'revolution' in communication that its smartphone, tablet computers, and wearable computers (such as Apple Watch) represent. ${ }^{11}$ These two cases of Windows and iPhone illustrate an oft encountered poor understanding of the communication needs, desires, and aspirations of people with disabilities. Often the resistance has been to do with the real or perceived cost, and also the belief that the market is fragmented and relatively small - and so cost will be high, revenue insufficiently, and profitability low. ${ }^{12}$ There are also complex issues of design, investigated and debated across various disciplines, where longstanding concepts of participatory, universal and inclusive design have been joined by work on the logics and promises of what disability adds. ${ }^{13}$

Against this scene of considerable energy and innovation in relation to disability participation in contemporary media and communications, we have the promise of the Convention on the Rights of Persons with Disabilities (CRPD), ${ }^{14}$ which celebrated its 10 th anniversary in 2016. The CRPD is a landmark in disability and human rights that has been widely celebrated and debated. Among other praiseworthy aspects, with the CRPD for the first time we witness an international convention that is predicated on communication and media as underpinning equal access and participation in society - and, as such, central to the achievement

10 On disability, accessibility and the iPhone, see Gerard Goggin, Global Mobile Media (Routledge, 2011).

11 See Gerard Goggin, 'Disability and Haptic Mobile Media' (2017) New Media and Society (doi: 10.1177/146144487717512).

12 On the politics and economics of digital technology, accessibility and digital markets, see Heide M Berven and Peter Blanck, 'Assistive Technology Patenting Trends and the Americans with Disabilities Act' (1999) 17(1) Behavioral Sciences $\&$ the Law 47; Gerard Goggin and Christopher Newell, 'The Business of Digital Disability' (2007) 24(2) Information Society 159; Karen Soldatic, Hannah Morgan and Alan Roulstone (eds), Disability, Spaces, and Places of Policy Exclusion (Routledge, 2014); Frederic Vannieuwenborg et al, 'Bringing eCare Platforms to the Market' (2016) 42(3) Informatics for Health and Social Care 207. For related debates on the potential markets and profitability of underserved or neglected groups, see Gloria Moss (ed), Lessons on Profiting from Diversity (Palgrave Macmillan, 2012).

13 Robert Imrie and Peter Hall, Inclusive Design: Designing and Developing Accessible Environments (Routledge, 2001); Robert Imrie, Accessible Housing: Quality, Disability and Design (Routledge, 2006); Graham Pullin, Design Meets Disability (MIT Press, 2011); Jos Boys, Doing Design Differently: An Alternative Handbook on Architecture, Dis/ability, and Designing for Everyday Life (Routledge, 2014); Charlotte Bates, Rob Imrie, and Kim Kullman (eds), Care and Design: Bodies, Building, Cities (Wiley-Blackwell, 2016).

14 Convention on the Rights of Persons with Disabilities, opened for signature 30 March 2007, 2515 UNTS 3 (entered into force 3 May 2008) (CRPD). 
of human rights. ${ }^{15}$ Specifically, it can be argued that: (1) the CRPD greatly advances communications rights for persons with disabilities in international law, through a number of specific provisions; (2) such communications rights are a requirement for the success of the broader project of human rights, justice, and equality for people with disabilities.

In articulating these arguments, I also acknowledge important critiques of the CRPD, which raise issues for how we might wish to conceptualise communications. These matters haunt and qualify the prospects of the CRPD, as they do national laws. While it is outside the purview to discuss such critiques in detail, I do wish to briefly add to these by suggesting that the lived experience, communication styles, media use and adoption of people with disabilities, challenge the orthodoxies of what is considered 'normal' or 'standard' communication. Ultimately, we need to build on these contemporary understandings of disability, as well as the CRPD, to achieve communications rights for all, especially people with disabilities.

In this article, my focus is exploring the relationships between the CRPD and national law, such as the Australian context, in the area of communications rights. In this area of communications rights, especially, it is essential to place law, policy, and regulation in social, political, and cultural context. To do this, I fashion an interdisciplinary framework that brings together different strands of theoretical and research traditions, especially socio-legal research, critical disability studies, ${ }^{16}$ media studies, ${ }^{17}$ and global media policy research. ${ }^{18}$ Against this background and framework, my article falls into three main sections. First, I discuss the evolution of communications rights and disability internationally, and what the CRPD represents for these (Part II). Secondly, I consider the 'scorecard' on the first decade of CRPD in relation to communications rights (Part III). Thirdly, I discuss the case of universal service in Australia, and,

15 Human rights have been long debated, and my approach draws upon recent critical scholarship in human rights, such as: Lynn Hunt, Invention Human Rights: A History (WW Norton, 2007); Samuel Moyn, The Last Utopia: Human Rights in History (Harvard University Press, 2010); Benjamin Gregg, Human Rights as Social Construction (Cambridge University Press, 2012). I also draw upon cultural studies accounts of human rights, such as: John N Erni, Cultural Studies, Human Rights, and the Legal Imagination: Reframing Critical Justice (Routledge, 2016); Bee Chen Goh, Baden Offord, and Rob Garbutt (eds), Activating Human Rights and Peace: Theories, Practices, and Contexts (Ashgate, 2012). Finally, I am indebted to a range of scholarship and conceptualisation of disability and human rights, especially that cited through this article.

16 Dan Goodley, Dis/ability Studies: Theorising Disablism and Ableism (Routledge, 2014); Magrit Shildrick, 'Critical Disability Studies: Rethinking the Conventions for the Age of Postmodernity,' in Nick Watson and Alan Roulstone (eds), Routledge Handbook of Disability Studies (Routledge, 2014) 30; Lennard Davis (ed), Disability Studies Reader (Routledge, 2016).

17 Katie Ellis, Gerard Goggin and Beth Haller (eds), Routledge Companion to Disability and Media (Routledge, 2017).

18 Marc Raboy and Robin Mansell (eds), The Handbook of Global Media and Communications Policy (Wiley-Blackwell, 2011). 
surprisingly, how the CRPD has not been seriously marshalled as a way of advancing this key element of communications rights (Part V). Finally, I offer concluding remarks (Part V), following other scholars in arguing the need for a comprehensive framework at the national level to deliver communications rights. However, rather than just focusing on accessible information and communication technologies (ICTs), web equality, internet rights, broadband internet, or mobile phones - which have featured heavily in scholarly, policy, and activist proposals in recent years - I argue for a truly comprehensive legal and policy framework - not only to deliver the communications rights embedded in the CRPD but also to leverage the treaty to remodel communications rights for all.

\section{Evolution of Communications Rights and Disability: The Breakthrough of the CRPD}

The right to freedom of speech and expression has long been part of the heritage and inventory of human rights. ${ }^{19}$ Recently, there has been increasing interest in extending the concept of rights to include communication and media. ${ }^{20} \mathrm{~A}$ shorthand for this has been provided in the idea that communications rights have the "characteristics of "third generation" human rights - where first generation are civil and political rights, and second generation are social and economic rights'. ${ }^{21}$ In proposing this idea, Thomas L Jacobson sees the 'third generation of rights, which include global concerns whose defense requires collective action by states and other international actors' - such as 'ecological balance'..${ }^{22}$ On the 'right to communicate', Jacobson offers the resonant observation that: 'This new

19 Tarlach McGonagle and Yvonne Donders (eds), The United Nations and Freedom of Expression and Information: Critical Perspectives (Cambridge University Press, 2015).

20 See Cees J Hamelink, The Politics of World Communication: A Human Rights Perspective (Sage, 1994); Aliaa Dakroury, Communication and Human Rights (Kendall Hunt, 2009); Bala A Musa and Jerry Komia Domatob (eds), Communication, Culture, and Human Rights in Africa (University Press of America, 2011) Vol 1. Of course, the issue of communications is integral to realising rights, so this has been widely canvassed - for instance, how and which non-state actors and individuals can provide communications concerning human rights treaties. See, for example, PR Gandhi, 'The Human Rights Committee and the Right to Individual Communication' (1986) 57(1) British Yearbook of International Law 201; Sonja C Grover, Children Defending Their Human Rights under the CRC [Convention on the Rights of the Child] Communications Procedure: On Strengthening the Convention on the Rights of the Child Complaints Mechanism (Springer, 2015).

21 Daithí Mac Síthigh, 'From Freedom of Speech to the Right to Communicate,' in Monroe E Price, Stefan G Verhulst and Libby Morgan (eds), Routledge Handbook of Media Law (Routledge, 2013) 176. Compare Deborah Hicks, 'The Right to Communicate: Past Mistakes and Future Possibilities' (2007) 3 Dalhousie Journal of Interdisciplinary Management <https://ojs.library.dal.ca/djim/article/ view/2007vol3Hicks/43>.

22 Thomas L Jacobson, 'Discourse Ethics and the Right to Communicate' (1998) 60(5) International Communications Gazette 395, 395. 
right is ethical in nature, being fundamental like the rights to life and liberty, but it has other complexities as well'. ${ }^{23}$ As well as the fact that the right to communicate became 'politically charged' at inception (as discussed shortly), and that it has implications for national development, Jacobson adds that there are also 'conceptual difficulties' in relation to the right's 'specific definition'. ${ }^{24}$ It is fair to say that communications rights have been relatively underdeveloped in philosophical, legal, and policy terms, in comparison with speech and expression rights. ${ }^{25}$

In Australia, there is a fundamental threshold issue about the constitutional and legal status of rights, as registered in proposals and debates on a bill of rights. ${ }^{26}$ Notwithstanding, freedom of speech and expression have tended to feature in the 'top table' of human rights conversations, ${ }^{27}$ without much explicit discussion of communications rights more broadly. However, there has been an important exception - the longstanding debate about the right to political communication. ${ }^{28}$ Leaving this aside, recently, with the transformations associated with digital technologies, there are new issues that have arisen and featured in research and debates. Such issues include how to conceptualise and safeguard speech, expression, and communications rights, as well as new challenges for how these domains might be regulated - not least the rise of non-state actors, especially in the form of transnational corporations owning and providing media platforms. ${ }^{29}$

If we retrace the development of late modern conceptions of communications rights, the oft-cited pioneering figure is Jean d'Arcy, with his celebrated remark that: "The time will come when the Universal Declaration of Human Rights will have to encompass a more extensive right than

23 Ibid.

24 Ibid.

25 See, for example, a recent useful volume that includes chapters on the contested nature of free speech rights (however, as is typical, nothing explicitly on communications rights): Rowan Cruft, S Matthew Liao and Massimo Renzo (eds), Philosophical Foundations of Human Rights (Oxford University Press, 2015).

26 See, for example, George Williams, A Bill of Rights for Australia (UNSW Press, 2000); George Williams, The Case for an Australian Bill of Rights: Freedom in the War on Terror (UNSW Press, 2004); George Williams, A Charter of Rights for Australia (2007); Tom Campbell, Jeffrey Goldsworthy and Adrienne Stone (eds), Protecting Rights without A Bill of Rights: Institutional Performance and Reform in Australia (Ashgate, 2006); Andrew Byrnes, Bill of Rights in Australia: History, Politics, and Law (UNSW Press, 2009); David Erdos, Delegating Rights Protections: The Rise of Bills of Rights in the Westminster World (Oxford University Press).

27 Katharine Gelber, Speech Matters: Getting Free Speech Right (UQP, 2011).

28 See, for example, George Williams and David Hume, Human Rights under the Australian Constitution (Oxford University Press, 2nd ed, 2013) Ch 5 'Freedom of Political Communication'.

29 See, for example, Monroe E Price, Stefaan G Verhulst and Emily Morgan (eds), Routledge Handbook of Media Law (Routledge, 2013); Emily B Laidlaw, Regulating Speech in Cyberspace: Gatekeepers, Human Rights, and Corporate Responsibility (Cambridge University Press, 2015). 
the right to information ... This is the right of men to communicate.' ${ }^{30}$ Discussion of the right to communicate was taken up by the United Nations Educational, Scientific and Cultural Organization (UNESCO) in the mid-1970s and eventually found support in a famous compromise recommendation in the MacBride report: 'In developing what might be called a new era of social rights, we suggest all the implications of the right to communicate be further explored. ${ }^{31}$ Cees Hamelink, perhaps the leading theoretician of the right to communicate, views the concept in an 'interactive sense', as something that involves a 'process of mutuality, making commonality, or creating a community'. ${ }^{32}$ Hamelink notes that from the 1970s the right to communicate was 'included in UNESCO's programs but over the following decades no consensus could be reached between protagonists and opponents'. ${ }^{33}$ When the right to communicate resurfaced in the preparations for the World Summit on the Information Society (WSIS), it became embroiled in a furious debate. ${ }^{34}$ In the postWSIS period, communications rights have sketched a somewhat different trajectory, with the centrality of the internet, mobile phone, new forms of video, television, cinema, radio, print, and associated digital technologies requiring considerable rethinking. A milestone moment occurred in 2011 with United Nations special rapporteur Frank La Rue's report noting that 'the framework of international human rights law remains relevant today and equally applicable to new communication technologies such as the Internet'. ${ }^{35}$

$30 \quad$ Jean d'Arcy, 'Direct Broadcast Satellites and the Right to Communicate' (1969) 118 EBU Review 14, 14.

31 MacBride Commission, Many Voices, One World: Communication and Society Today and Tomorrow: Towards a New, More Just, and More Efficient World Information and Communication Order, Report by the International Commission for the Study of Communication Problems (Kogan Page and UNESCO, 1980) 265. For a contemporary perspective, see Desmond Fisher and Leroy Stanley Harms (eds), The Right to Communicate: A New Human Right (Boole Press, 1983). For a useful retrospective, see Alan McKenna, 'The Right to Communicate: A Continuing Victim of Historic Links to NWICO and UNESCO?' in Divina Frau-Meigs et al (eds), From NWICO to WSIS: Actors and Flows, Structures and Divides (Intellect, 2012) 93.

32 Cees J Hamelink, 'Communication Rights and the History of Ideas' in Claudia Padovani and Andrew Calabrese (eds), Communication Rights and Social Justice: Historical Accounts of Transnational Mobilizations (Palgrave Macmillan, 2014) 22.

33 Ibid.

34 See Association for Progressive Communications (APC), The Status of Critical Communication Rights Ten Years after the World Summit on the Information Society (WSIS): A Report Documenting Civil Society Perceptions (2013) <http:// www.apc.org/en/projects/communications-rights-ten-years-after-wsis-civil-s>; Marc Raboy and Jeremy Shtern, 'Histories, Contexts, and Controversies,' in Marc Raboy and Jeremy Shtern (eds), Media Divides: Communication Rights and the Right to Communicate in Canada (University of British Columbia Press, 2010) 26; Pradip Ninan Thomas, Negotiating Communications Rights: Case Studies from India (Sage, 2011).

35 Frank La Rue, Report of the Special Rapporteur on the Promotion and Protection of the Right to Freedom of Opinion and Expression, 17th sess, UN Doc A/ 
Throughout this history of communications rights, disability has been - and still remains - largely invisible. ${ }^{36}$ Despite the dearth of disability in communications rights discussion, if we look at a wide range of disability research, policy, activism, and debates we find that issues of communications rights often figure. For example, various scholars and activists have raised the issues of people with speech impairments being denied the right to communicate - something that often has direct, deleterious consequences in relation to how people fare in institutional settings, health and social services, work and education, courts and criminal justice, let alone in the cultural realm, political participation, friendship, and intimate citizenship. ${ }^{37}$ Such disability perspectives on communications rights, however, have not been systematically elaborated, and only rarely have they been joined to broader discussions.

Once we do engage disability in questions of communications rights, we need to acknowledge and explore the deep normative underpinning of communication that shapes and subtends such concepts of rights and their claims. Notably, we are drawn into the broader debate about what is communication. Thus the right to communication inexorably involves the right to express oneself in one's own style, means, and idiom, and, in needing or wishing to do so, communicate differently from the 'norm'. The acknowledgment of different kinds, modes, and models of communication is something that has been raised in the case of stuttering in the workplace, ${ }^{38}$ as it has been in explorations of what makes sense (or counts as intelligible communication) in the case of people with mental or psychiatric disabilities. ${ }^{39}$ The right to communicate also involves acknowledging and understanding the socio-linguistics and requirements of sign languages and the deaf and other communities who use such languages. ${ }^{40}$

HRC/17/27 (16 May 2011) 1, 7 <http://www2.ohchr.org/english/bodies/hrcouncil/ docs/17session/A.HRC.17.27_en.pdf >; cf Mac Síthigh, above n 21, 186.

36 A pioneering paper on the topic is Julia Hoffman and Alia Dakroury, 'Disability Rights between Legal Discourses and Policy Narratives: An Analysis of the European and Canadian Frameworks' (2013) 33(3) Disability Studies Quarterly $<$ http://dsq-sds.org/article/view/1778/3260>. See also remarks in Cees Hamelink, above n 32, 23, and his paper 'Toward a Human Right to Communicate?' (2004) 29(2) Canadian Journal of Communication $205<\mathrm{http}: / / \mathrm{www}$.cjc-online.ca/index. php/journal/article/view/1436/1548>.

37 See, for example, Jenny Morris, 'Impairment and Disability: Constructing an Ethics of Care that Promotes Human Rights' (2001) 16(4) Hypatia 1; Sally French and John Swain, 'Disability and Communication: Listening is Not Enough' in Martin Robb et al (eds), Communication, Relationships, and Care (Routledge, 2004) 220; Teppo Kröger, 'Care Research and Disability Studies: Nothing in Common?' (2009) 29(3) Critical Social Policy 398.

38 Jared Gilman, 'Disability or Identity?: Stuttering, Employment Discrimination, and the Right to Speak Differently at Work' (2012) 77(3) Brooklyn Law Review 1179 <http://brooklynworks.brooklaw.edu/blr/vol77/iss3/7>.

39 Judi Chamberlain, 'Citizenship Rights and Psychiatric Disability' (1998) 21(4) Psychiatric Rehabilitation Journal 405.

40 See, for example, Jennifer Harris and Claire Bamford, 'The Uphill Struggle: Services for Deaf and Hard of Hearing People: Issues of Equality, Participation, and Access' (2001) 16(7) Disability \& Society 969; Harlan Lane, 'Do Deaf People 
The questions of what communication entails and how we imagine it is also very much at the heart of discussions of communications rights for people with intellectual disabilities. ${ }^{41}$ Social interaction - for instance, with one's peers in a classroom as well as the teacher - is an important element of communications rights not always afforded to people with disabilities. ${ }^{42}$ Add to which communications rights are a fraught affair for children, let alone for children with disabilities. ${ }^{43}$

To summarise, communications rights for people with disabilities needs serious, systematic consideration. In this process, disability communications rights perspectives are an important resource for reimagining general communications rights. Indeed, we find such rethinking of communications rights nascent across various settings, including the idea of using 'listening' as a generative concept drawing on disability communication, rights, and justice. ${ }^{44}$

For the purposes of this article, I take up the story from a watershed moment in the development of communications rights for people with disabilities - the WSIS. Despite the unique opportunity WSIS presented for civil society participation in global policy discussions, disability advocates and delegates felt shut out from the first meeting of WSIS in Geneva in 2003. To overcome this marginalisation, the WSIS Disability Caucus organised a second forum for the 2005 Tunis meeting. ${ }^{45}$ This historic 2 nd

Have a Disability?' (2002) 2(4) Sign Language Studies 356; Jan Branson and Don Miller, Damned for Their Difference: The Cultural Construction of Deaf People as Disabled (Gaulladet, 2001); Marc Marschark and Patricia Elizabeth Spencer (eds), Oxford Handbook of Deaf Studies, Language, and Education (Oxford University Press, 2010) Vol 2.

41 See, for example, Leonie Armstrong, 'The Reality of Rights: People With an Intellectual Disability and the Criminal Justice System' (1997) 3(2) Australian Journal of Human Rights 78; Caroline Dalton and John Sweeney, 'Communication Supports in Residential Services for People with an Intellectual Disability' (2013) 41(1) British Journal of Learning Disabilities 22.

42 Allan H Maccurdy, 'Rights Respiration: Disability, Isolation, and a Constitutional Right of Interaction' (2007) 13(2) Texas Wesleyan Law Review 737.

43 On children with disability and communication experiences and rights, see Belinda Garth and Rosalie Aroni, "I Value What You Have to Say": Seeking the Perspective of Children with a Disability, Not Just Their Parents' (2003) 18(5) Disability \& Society 561; Meryl Alper and Gerard Goggin, 'Digital Technology and Rights in the Lives of Children with Disabilities' (2017) 19(5) New Media \& Society 726.

44 See, for example, Tanja Dreher, 'Listening Across Difference: Media and Multiculturalism Beyond the Politics of Voice' (2009) 23(4) Continuum 445; Gerard Goggin, 'Disability and the Ethics of Listening: New Models for Democracy and Media' (2009) 23(4) Continuum 489; Tanja Dreher and Cate Thill, 'Listening for Policy Change: How the Voices of Disabled People Shaped Australia's National Disability Insurance Scheme' (2015) 30(1) Disability \& Society 15.

45 For an explanation and discussion of how disability advocates achieved this important intervention into global media policy and communications rights at WSIS, see Gerard Goggin, 'Communication Rights and Disability Online: Policy and Technology after the World Summit on the Information Society (WSIS)' (2015) 18(3) Information, Communication \& Society 327. 
Forum culminated in the Tunis Declaration on the Information Society for Persons with Disabilities, wherein delegates:

2. Strongly urge that persons with disabilities and our needs be included in all aspects ... of information and communication technologies ... so as to ensure accessibility for persons with disabilities, taking into account the universal design principle and the use of assistive technologies ... [and]

4. Urge all governments to support the process of negotiation, adoption, ratification and implementation of the International Convention on the Rights of Persons with Disabilities. ${ }^{46}$

In his review of disability in WSIS a decade later (WSIS +10), Axel LeBlois suggests that: 'WSIS was the first global venue where the accessibility of ICTs for persons with disabilities was defined as a condition for persons with disabilities to fully participate in society and enjoy all fundamental freedoms. ${ }^{\prime 4}$

If WSIS was the first global venue, it was the CRPD which quickly eclipsed its predecessor to become the second and certainly most important global venue for disability and communications rights. The most obvious contribution the CRPD makes is that it explicitly incorporates the most famous right - that of freedom of expression - to ensure there is no doubt that it applies to people with disabilities. Recall Art 19 of the Universal Declaration of Human Rights:

Everyone has the right to freedom of opinion and expression; this right includes freedom to hold opinions without interference and to seek, receive and impart information and ideas through any media and regardless of frontiers. ${ }^{48}$

The CRPD builds upon Art 19 to set out a detailed provision on freedom of expression and opinion that addresses a number of issues for people with disabilities and deaf people. The key Article here is Art 21 of the CRPD:

Article 21 - Freedom of expression and opinion, and access to information

States Parties shall take all appropriate measures to ensure that persons with disabilities can exercise the right to freedom of expression and opinion, including the freedom to seek, receive and impart information and ideas on an equal basis with others and through all forms of communication of their choice, as defined in article 2 of the present Convention, including by:

(a) Providing information intended for the general public to persons with disabilities in accessible formats and technologies appropriate to different kinds of disabilities in a timely manner and without additional cost;

(b) Accepting and facilitating the use of sign languages, Braille, augmentative and alternative communication, and all other accessible means, modes and formats of communication of their choice by persons with disabilities in official interactions;

$46 \quad$ Global Forum on Disability, Tunis Declaration on Information Society for Persons with Disabilities (2005) <http://www.dinf.ne.jp/doc/english/prompt/051118_declaration_wsis.html>.

47 Alex LeBlois, WSIS +10: Review and Strategic Directions for Building Inclusive Knowledge Societies for Persons with Disabilities (UNESCO, 2013) 7.

48 Universal Declaration of Human Rights, GA Res 217A (III), UN GAOR, 3rd sess, 183rd plen mtg, UN Doc A/810 (10 December 1948) Art 19. 
(c) Urging private entities that provide services to the general public, including through the Internet, to provide information and services in accessible and usable formats for persons with disabilities;

(d) Encouraging the mass media, including providers of information through the Internet, to make their services accessible to persons with disabilities;

(e) Recognizing and promoting the use of sign languages.

Simply taking Art 21 in its narrowest construction, it would be important to study and understand how it is put into force by states parties, which I shortly discuss. However, I also argue that CRPD goes well beyond such a narrow construction, to expand and alter taken-for-granted communications rights; and in the process, creates new dimensions of communications rights that states need to acknowledge and deliver. In different ways, the two most authoritative and systematic international studies available make this argument. Eliza Varney regards the 'rights-based approach advanced by the [CRPD]' as a 'benchmark in protecting the rights of persons with disabilities to have equal access to information' ${ }^{49}$ In his study of the ADA and the CRPD, Peter Blanck makes a spirited case for the right of everyone to 'web equality', to full use of the web and associated internet technologies. ${ }^{50}$ Specifically, Blanck sees the CRPD, along with the ADA and other instruments, as articulating a right to 'web content equality', as the 'opportunity for comparable use of web content by users with cognitive disabilities in ways that are reasonable under the circumstance' ${ }^{51}$ If it is true, as Varney, Blanck, myself, and others would argue, that the CRPD greatly expands our concepts of communications rights, the ways these are construed and enforced internationally fall a well way short of such a vision. So, why would this be so?

From the available research, it would appear that countries vary in how they draw upon or implement the CRPD when it comes to communications rights (see, for instance, the difference between European and Canadian implementation of the Treaty). ${ }^{52}$ Doubtless further comparative research across other jurisdictions can add insight to this picture. However, for the purposes of my argument concerning the need for a comprehensive approach to communications rights, I would identify another possibility. A more substantial discussion will await another occasion, but suffice to propose here that attention of the United Nations, its agencies, and member states has focused upon accessibility of digital technologies rather than, for instance, the wider implications of the 'classic' rights to freedom of expression and opinion conveyed in Art 21 of the CRPD.

Here the lead has been taken by the organisation called G3ICT, an 'advocacy initiative launched in December 2006 by the United Nations Global Alliance for ICT and Development, in cooperation with the

49 Eliza Varney, Disability and Information Technology: A Comparative Study in Media Regulation (Cambridge University Press, 2013) 208.

50 Peter Blanck, eQuality: The Struggle for Web Accessibility by Persons with Cognitive Disabilities (Cambridge University Press, 2014) 35.

51 Ibid.

52 Hoffman and Dakroury, above n 36. 
Secretariat for the Convention on the Rights of Persons with Disabilities' ${ }^{53}$ In a relatively short span of time, G3ICT has achieved a great deal, notably through its research, reports, and resources, but especially through its well-known 'M-Enabling' conferences. When we look at the mandate, activities and achievements of G3ICT, it is very much focused on digital accessibility - albeit across many domains (including, for instance, education). The 'path dependency' here is remarkable. There is a line that connects various efforts over decades, including the Macbride ${ }^{54}$ and Maitland Reports, ${ }^{55}$ global media policy on communications and telecommunications for development, the information superhighway debates of the 1990s, WSIS, and, in 2015-2016, the Sustainable Development Goals of the 2030 Agenda for Sustainable Development (SDGs). If we take the SDGs as an example, how they operationalise communications rights is via a specific goal on diffusion of 'universal and affordable access to the Internet in least developed countries by 2020'. ${ }^{56}$ Enabling technology in relation to women is also a specific goal. ${ }^{57}$ Disability features in a number of places in the SDGs; however, there is no specific mention of communication. Rather, disability and communication is most prominently taken up through the work of G3ICT, as well as a wide range of work by many other actors in the ICT for development (ICT4D) and mobiles for development (M4D) communities of research and practice. This work is vitally important, and is often coeval with human rights approaches. However, the dual focus on digital technology accessibility and communications for development does not squarely and comprehensively raise and follow through the full dimensions of communications rights for people with disabilities, as indicated by the CRDP. This background and critique is important for my argument and ensuing analysis of the implementation of the CRPD in the various areas of communications rights it engages, to which I now turn.

\section{Scorecard on Communications Rights: How Has the CRPD Been Implemented?}

As we move into its second decade, there is a substantial literature on the implementation and impact of the CRPD ${ }^{58}$ Like most international law,

$\overline{53}$ The Global Initiative for Inclusive ICTs, About G3ICT (2016) <http://www.g3ict. org/about>.

54 MacBride Commission, above n 31.

55 Report of the Independent Commission for World Wide Telecommunications Development (Maitland Report) (ITU, 1984) < http://www.itu.int/osg/spuold/sfo/ missinglink/index.html>.

56 Transforming Our World: The 2030 Agenda for Sustainable Development, GA Res 70/1, UN GAOR, 70th sess, UN Doc A/Res/70/1 (25 September 2015) Goal 9c.

57 Ibid Goal 5b.

58 See, inter alia, Oddný Mjöll Arnardóttir and Gerard Quinn (eds), The UN Convention on the Rights of Persons with Disabilities: European and Scandinavian Perspectives (Martinus Nijhoff, 2009); Eilionóir Flynn, From Rhetoric to Action: Implementing the UN Convention on the Rights of Persons with Disabilities 
especially treaties, its influence and power varies, so close examination of the domestic law, political arrangements, and social contexts is key. In her examination of regulation of information technology and disability in four jurisdictions - Canada, the US, the European Union, and the United Kingdom - Varney finds a large gap between the requirements of the CRPD and what these countries have put in place. ${ }^{59}$ Varney contends that: 'Regulatory frameworks must move away from a hierarchy of disabilities in the regulation of ICTs and must offer accessibility solutions that rely on a wide definition of disability.' ${ }^{60}$ Varney also notes the potential for the CRPD to "provide the basis for ... facilitating international cooperation in the regulation of private service providers that operate beyond national confines'. ${ }^{61}$

For his part, Blanck also finds strong support for expanded, modern definitions of communications rights for people with disabilities, especially those with cognitive disabilities - notably via his notion of web equality. Blanck's discussion focuses on a range of specific US laws that safeguard such equality, in conjunction with other dynamics such as business initiatives, design, standards, and research and practice. ${ }^{62}$ Here there is a very interesting underlying issue that is highlighted by these two authoritative studies (alongside others), about how the CRPD plays out to activate human rights in the area of communication. Much of the action remains at the local level, even if inspiration and potential support have been greatly buttressed internationally with the advent and growing influence of the CRPD. Let us now examine these dynamics in the case of Australia.

In Australia, the key legal change in the wake of the CRPD was the 2009 amendment to the Disability Discrimination Act 1992 (Cth). There is a growing literature on how the CRPD has influenced Australian law. There is little discussion, however, on the communication-related provisions of the CRPD and how these have shaped or improved communication aspects of human rights in Australia.

In terms of official reporting on CRPD implementation, Australia is one of the few countries to have lodged a report, which it did in 2012. In relation to Art 21, Australia reports on three items: 'Access to the Internet for persons with disabilities'; 'National information and captioning services for person [sic] with hearing impairment'; and 'Print disability services

(Cambridge University Press, 2011); Maya Sabatello and Marianne Schulze (eds), Human Rights and Disability Advocacy (University of Pennsyvlania Press, 2013); Arlene S Kanter, The Development of Disability Rights under International Law: From Charity to Human Rights (Routledge, 2015); Peter Blanck and Eilionóir Flynn (eds), Routledge Handbook of Disability Law and Human Rights (Routledge, 2017).

59 Varney, above n 49, 233.

60 Ibid.

61 Ibid 6.

62 Blanck, above n 50. 
for persons with visual impairment'. ${ }^{63}$ The content of each of these three items leaves much to be desired. For instance, the report notes there is an obligation under s 24 of the Disability Discrimination Act that any person or organisation providing a website in Australia ensure it is accessible. The report also notes the requirement for Australian government departments and agencies to adopt common web accessibility standards (this is the former National Transitional Strategy, though this is not named). Nothing is stated in terms of actual compliance or performance. Also disappointing is the section on captioning, which mentions obligations for broadcast of free-to-air television, and other items - however, is silent on the fast-emerging areas of subscription television, streaming services, as well as other areas of online and mobile video. Additional elements of communications rights are addressed in the Australian Government reporting under Art 30, such as support for commercial cinema to 'fast track' audio description and captioning technology, and also Australian provisions on access to copyright material for blind people and those with a vision impairment. ${ }^{64}$ What is perhaps most telling is that the Australian Government report contains no mention of any overarching strategy or framework when it comes to communications, media, and ICTs. In contrast, a range of other areas of disability human rights are prefaced or framed via mention of a specific strategy.

In its response to Australia's report, the Committee on the Rights of Persons with Disabilities (CRPD Committee) commends Australia in a number of general areas (including the National Disability Strategy and National Disability Insurance Scheme). However, the Committee also raises concerns about a number of shortcomings. In relation to Art 21, the CRPD Committee expresses concern at:

the State's party failure to provide all information in accessible formats and effectively promote and facilitate the use of Australian Sign Language (Auslan) as Australia's official sign language, as well as the use of all other forms of accessible formats of communication (deaf-blind interpretation, Braille, easy and plain English, audio description), in particular when persons with disabilities are engaged in official interactions. ${ }^{65}$

The CRPD Committee provides no commentary or challenge to the issues in Art 30. We now await the Australian Government's response, due by July 2018.

Given the nature of this United Nations monitoring process, we will be waiting a long time indeed for this process to bolster the resolve of governments to deliver communications rights. It also tells us little about the actual conceptualisation and state of play of communications rights

63 Australian Government, Implementation of the Convention on the Rights of Persons with Disabilities: Initial Reports Submitted by State Parties under Article 35 of the Convention, 107th-109th mtg, UN Doc CRPD/C/AUS/1 (7 June 2012) 29.

64 Ibid 39-40.

65 Committee on the Rights of Persons with Disabilities, Concluding Observations on the Initial Report of Australia, 10th sess, CRPD/C/AUS/CO/1 (21 October 2013) 6. 
for places like Australia. Hence, we need to take a broader, longer, and sharper view - informed by the specific struggles and evolving use, practice, and needs, as well as an understanding of the international picture.

If we look at the development of communications rights and disability in Australia, we can point to a number of legal milestones. Because of the lack of press legislation and regulation in Australia, there is little explicit law and little policy to build on for more recent communication and media. Where disability enters into communications and media law is especially in the province of broadcasting and telecommunications, which still provide Australia's two main sources of communications market and industry law and policy. Both of these areas of law undergird the two key media in the 1990-2010s period: internet and mobiles. As well as these media laws, the watershed in human rights and related anti-discrimination law comes with the Disability Discrimination Act.

The first landmark case under the Disability Discrimination Act was in the area of telecommunications - the 1995 inquiry by the Human Rights and Equal Opportunity Commission (HREOC) known as Scott $v$ Telstra. ${ }^{66}$ The next landmark action under the Disability Discrimination Act also engaged communications - concerning the relatively new area of web accessibility. In a world first, a blind person, Bruce Maguire, asserted his right to gain access to the website of the Sydney Olympics, as well as program and ticketing information, and had this affirmed by the HREOC. ${ }^{67}$ In subsequent years, the Disability Discrimination Act has been invoked and the Human Rights Commission engaged in complaints and conciliation on a range of communication issues, including captioning of cinema, television, and video, and audio description of such media, among other issues.

It is fair to say, then, that the summary judgment on the anniversary of 25 years of the Disability Discrimination Act in Australia is a very mixed picture. On the one hand, there has been some important

$66 \quad$ Scott v Telstra Corporation Ltd (Human Rights and Equal Opportunity Commission (HREOC), Sir Ronald Wilson (Inquiry Commissioner), Nos H95/34, H95/31, 19 July 2015) <https://www.humanrights.gov.au/ geoffrey-scott-v-telstra-corporation-limited>.

67 The three relevant cases are: Maguire v Sydney Organising Committee for the Olympic Games (HREOC, William Carter QC (Inquiry Commissioner), No H99/115, 18 October 1999) <https://www.humanrights.gov.au/maguire-vsocog>; Maguire v Sydney Organising Committee for the Olympic Games (HREOC, William Carter QC (Inquiry Commissioner), No H99/115, 24 August 2000) <https:// www.humanrights.gov.au/bruce-lindsay-maguire-v-sydney-organising-committee-olympic-games>; Maguire v Sydney Organising Committee for the Olympic Games (HREOC, William Carter QC (Inquiry Commissioner), No H99/115, 18 November 2000) <https://www.humanrights.gov.au/bruce-lindsay-maguirev-sydney-organising-committee-olympic-games-respondent-h-99115-2000> (concerning relief). For discussion of the enduring significance of these cases, see Gerard Goggin, Scott Hollier and Wayne Hawkins, 'Internet Accessibility and Disability Policy: Lessons for Digital Inclusion and Equality from Australia' (2017) 6(1) Internet Policy Review <https://policyreview.info/articles/analysis/ internet-accessibility-and-disability-policy-lessons-digital-inclusion-and>. 
progress on communications rights. On the other hand, progress has been typically slow and highly contested by many powerful industry interests. Unfortunately, there has been little countervailing pressure from governments, who have tended not to be supportive of complaints and test cases. On the whole, federal governments have also been reluctant to support extension, implementation, education, and enforcement of communications rights. Despite a clear and expanded vision of and mandate for communications rights having been articulated internationally, Australian governments have been grudging and unimaginative in their responses. There are many areas to discuss in this parlous situation, and here I wish to develop this analysis and argument via the pivotal case of universal service: the matter of access to communications for all, especially digital communications.

\section{Communications Rights: The Case of Universal Service in Australia}

The idea of access to communications for all has a history that can be traced back to the first decades of the 20th century. In telecommunications, the concept become known as universal service, with its origins in doctrine developed in the US. Debate has ensued ever since about the balance of industry strategy versus customer and citizen connectivity in such visions. As initially formulated, universal service was very much bound up with the desire of particular companies to provide widespread service. By the 1970 s, however, it had become a concept that underpinned the entitlement and right of citizens to telephone service regardless of where they lived - in rural or city areas. ${ }^{68}$ As the 1990s proceeded, universal service became widely debated precisely because of fears that the introduction of competition and shift from public to private, market-based provision of telecommunication would endanger access and service levels. In Australia, it was explicitly incorporated in the Telecommunications Act 1991 (Cth).

While universal service became a staple of international telecommunications law and policy, and widely accepted as a right of citizens, in practice it varied widely. Furthermore, constitutive dimensions of universal service were typically overlooked, such as affordability and the inclusion of new kinds of communication service. Across many jurisdictions, universal service remained quarantined at a basic level of service - typically a voice equivalent service. With the growing importance and prevalence of broadband in the early 2000s, pressure mounted on policy-makers to upgrade the definition to include broadband. However, few jurisdictions did so. Similarly, arguments were made that universal service should include mobile service, or at least acknowledge the crucial

68 See, for example, Ian R Wilson and Gerard Goggin, Reforming Universal Service: The Future of Consumer Access and Equity in Australian Telecommunications (Consumers' Telecommunications Network, 1993); Bruce Langtry (ed), All Connected? Universal Service in Telecommunications (University of Melbourne Press, 1998). 
mobility element of contemporary communications ${ }^{69}-$ and, despite the reliance on mobile, wireless, and microwave networks to deliver universal service in many markets (especially in developing countries), this has typically been overlooked.

Where a highly significant change was made to universal service across many jurisdictions was in relation to disability and accessibility. In Australia, many people with disabilities had been long excluded from the telephone network, and then the telecommunications network, as its successor. ${ }^{70}$ Despite increasing awareness of this issue, the definition of universal service in the Telecommunications Act 1991 (Cth) ignored accessibility and disability issues. In essence, the standard telecommunications service fundamentally lacked imagination, being based on the norm of the voice telephone. It did not extend to the kinds of telecommunication devices that many users with disabilities and deaf users actually relied upon. This led to the aforementioned complaint made by a deaf man from Western Australia, Geoff Scott, joined by Disabled Peoples' International (Australia). ${ }^{71}$ The distinguished Commissioner and President of the HREOC, Sir Ronald Wilson, found against Telstra. ${ }^{72}$ Responding to this decision, the federal government changed the legislation, so that the definition of universal service in the Telecommunications Act 1997 (Cth) contained an accessibility principle. Henceforth, the universal service carrier was obliged to provide a voice-equivalent service to all people with disabilities who required it. This definition of universal service was subsequently carried over to Telecommunications (Consumer Protection and Service Standards) Act 1999 (Cth), which is still in force. Among other measures, these changes to the legal framework led to a Disability Equipment Fund, operated by Telstra, to provide a range of accessible telecommunications equipment for customers with disabilities.

All in all, the legal, policy, and corporate changes effected in the wake of Scott $v$ Telstra added up to a historical step in communications rights for people with disabilities. However, in the intervening two decades, while there have been various service and policy improvements, there has been no fundamental change to this concept of universal service despite the dramatic change in technology, social practices, and cultures of use. While facing considerable barriers and differential patterns of use, ${ }^{73}$ Deaf people and people with disabilities are avid users of digital

$69 \quad$ Patrick Burkart, 'Moving Targets: Introducing Mobility into Universal Service Obligations' (2007) 31(3-4) Telecommunications Policy 164.

70 For full discussion see Gerard Goggin and Christopher Newell, 'Crippling Competition: Critical Reflections on Disability and Australian Telecommunications Policy' (2000) 96 Media International Australia 83.

71 See Michael Bourk, 'Scottv Telstra:A Watershed in Australian Telecommunications Policy' (2000) 96 Media International Australia 69.

72 Scott v Telstra Corporation Ltd (Human Rights and Equal Opportunity Commission (HREOC), Sir Ronald Wilson (Inquiry Commissioner), Nos H95/34, H95/31, 19 July 2015).

73 See recent data that shows Australians with disabilities across all States consistently experiencing lower rates of 'digital inclusion' than the general population: 
technologies. Yet the standard communication service remains out-ofdate - it is modelled on the voice telephone, not the text, video, audio, or multi-media technologies people with disabilities use. This situation is set to change via the overdue efforts of the Australia Government to examine and potentially reform universal service - especially through the 2016-2017 Productivity Commission Inquiry into Telecommunications Universal Service Obligation.

The Productivity Commission provides a clear statement that the universal service obligations and arrangements are well outdated, and require major change. In its Final Report the Commission suggests a new universal service policy objective 'couched in terms of delivering a baseline level of telecommunications services to all Australians'. ${ }^{74}$ There is also considerable discussion of disability and accessibility issues. The key finding is that with regard to people with disability (among other groups), 'government intervention is likely to be warranted to target their particular needs' ${ }^{75}$ The Productivity Commission canvasses the establishment of a universal service fund, with one part of this to explicitly address affordability and accessibility issues. Underpinning the suggested approach are various principles, in particular that a telecommunications universal service objective should be, among other things, 'based on clear definitions of universal access and service and their scope; [and] specified in the form of measurable user outcomes' ${ }^{76}$ This sounds promising, but there is an overarching problem here. While the Productivity Commission canvasses specific matters concerning consumers with disabilities, and also whether universal service should include the principle of accessibility, it is notable that broader aspects of disability, communications, and rights do not frame its terms of reference, issues paper, or final report. ${ }^{77}$ Nor is the CRPD mentioned once. Rather, the Productivity Commission notes that the issues of rights will be addressed in an intended federal government review of the telecommunications consumer safeguard framework (and the Commission urges the government to do this as a priority). ${ }^{78}$

It remains to be seen in what way the foreshadowed review of telecommunications consumer safeguards will engage notions of communications rights, especially those relating to disability and framed by the CRPD. However, there remains a broader problem of the compartmentalisation in communications law and policy - which remains widespread, but has

Julian Thomas et al, Measuring Australia's Digital Divide: The Australian Digital Inclusion Index 2016 (Swinburne University of Technology, Melbourne, and Telstra, 2016) <http://digitalinclusionindex.org.au/the-index-report/report/>.

74 Productivity Commission, Telecommunications Universal Service Obligation, Inquiry Report 83 (2017) 33.

75 Ibid 197.

76 Ibid 33.

77 Productivity Commission, Telecommunications Universal Service Obligation, Issues Paper (2016) <http://www.pc.gov.au/inquiries/current/telecommunications/ issues>.

78 Productivity Commission, above n 74, 347. 
particular implications for rights. The relation between questions of digital networks (that telecommunications continues to exemplify) and other forms of the changing communication landscape is something is lacking systemic treatment and coverage.

For instance, the Disability Discrimination Act has been invoked and the Human Rights Commission engaged in complaints and conciliation on a range of communication issues, including captioning of cinema, television, and video, and audio description of such media. While space precludes full discussion of these various cases, suffice to say that important advances in access to media have occurred through such recourse by complainants to the Disability Discrimination Act.

Yet the overall picture is that progress is far too slow, and that in many emerging areas of media, specific law and regulation on obvious areas for people with disabilities (and other consumers) are missing - to the extent consumers and citizens lack effective, affordable, and expedient ways to assert claims of rights against market participants. Recourse may be had in some of these instances to the Disability Discrimination Act, but the ability of the institutions (namely the Human Rights Commission) to effect systematic protection of rights in a fast-moving, technologysaturated media landscape is very limited.

A good example can be seen in the case of people with disabilities and access to and consumption of streaming video services, offered in Australia through well-known international companies such as Netflix, as well as local ventures such as Stan. In their pioneering 2016 research, Katie Ellis and co-authors give a snapshot of the burgeoning consumption of streaming video by people with disabilities, despite the significant challenges to accessibility they face. This research found that none of the video-on-demand providers had accessibility policies in place, nor was video-on-demand accessibility required under the relevant legislation, the Broadcasting Service Act 1992 (Cth) (which works in conjunction with the Disability Discrimination Act).$^{79}$ Their research, and other emerging work, ${ }^{80}$ squarely puts on the agenda the need for regulation to ensure accessibility of such emergent media - a crucial area of communications rights.

So, there is a two-fold problem here. First, Australia lacks an overarching legal and policy framework on communications rights, something especially urgent given the transformations in this area in recent years. Secondly, the key human rights legislation and institution, namely the Disability Discrimination Act and Human Rights Commission, lack the ability to tackle the wide range of new frontiers of communications, and

79 Katie Ellis et al, Accessing Subscription Video on Demand: A Study of Disability and Streaming Television in Australia (Australian Communication Consumer Action Network, 2016) <https://accan.org.au/grants/current-grants/1066accessing-video-on-demand-a-study-of-disability-and-streaming-television>.

80 See, for example, Wayne Hawkins, 'Video on Demand: The New Disability Divide?' in Katie Ellis, Gerard Goggin and Beth Haller (eds), Routledge Companion to Disability and Media (Routledge, 2018) (forthcoming). 
powerful global players (for instance, in streaming television or social media industries) - to extend potential tools and safeguards to citizens facing potential violations of communications rights. This is precisely why Australian consumer and disability rights advocates have called for a Communications and Video Accessibility Act to mandate minimum standards on accessibility for content and communication services, modelled on the US 21st Century Communications and Video Accessibility Act 2010. ${ }^{81}$ As yet, such calls have gone unheeded.

\section{Conclusion: Why the CRPD Has Not Made More of a Difference in Communications Rights Nationally}

There is something of a consensus that the CRPD represents a major advance in communications rights internationally. As I have indicated, the change to communications rights for people with disabilities portended by the CRPD is arguably far-reaching indeed. I also have argued that this urgent project of securing communications rights for people with disabilities has broader implications. Namely, that rethinking disability and communications, in all its diversity and implications, enriches and expands our taken-for-granted assumptions and norms of communications. This is an important project if we are to rethink and activate communications rights for all, not just people with disabilities. Amidst these hopes, there is a specific question to be asked: why hasn't the CRPD made more of a difference in the advancement of communications rights in national contexts such as Australia?

First, as I note, it depends on the view of particular jurisdictions regarding the CRPD. Here Australia falls well short, compared to what has been noted in available research about Europe or the US - at least in certain strategically important areas of communication, such as the pivotal and dynamic areas of digital technologies. As well as the distinctive legal traditions in Australia relating to rights, influenced by the United Kingdom in particular, there is a complex political economy and set of social and geopolitical contexts at play. Notably, Australia is not a 'hub' of the big digital media corporations and industries. The titans of the international media industries, especially the massive digital technology, internet, mobile, and social media corporations that dominate regionally (in the Asia-Pacific, for instance) as well as globally, are simply not headquartered in the antipodes.

Secondly, there are complex questions of how communications rights are conceived in contemporary Australia, and to what extent such rights have purchase in politics, law, society and institutions. Unfortunately, not much would be the short response. There is a palpable irony here. On the one hand, the transformations in media have opened up potent

81 Pub L No 111-260. See Australian Communications Consumer Action Network, 'ACCAN Calls for New Accessibility Laws' (Media Release, 14 August 2013) $<$ http://accan.org.au/our-work/616-accan-calls-for-new-accessibility-laws>. 
new possibilities that substantially extend the capabilities and options across many societies and groups, including those who have experienced striking exclusion and lack of access from earlier forms of communication. On the other hand, many people still face issues of digital inequality and communication inequality generally, something that has potentially greater implications today for their social and political participation. So, there is an even greater relevance and need for communications rights, and for these to be properly articulated and secured in accessible and fair legal frameworks and processes.

If it is true that communications rights languish, then disability communications rights provide an important opportunity. As many have noted, despite notable improvements in disability access and participation in media and communications, and the great promises offered by emergent technologies, systematic exclusion remains - even in new technologies. In this situation, a comprehensive framework on disability and communications rights for Australia law and policy is a key step forward. Yet, such an obvious step forward seems a pipe dream. But it is this kind of comprehensive framework that is surely an urgent task - especially if Australia is to adequately grasp and activate the communications rights so suggestively encapsulated in the epochal CRPD treaty. 